\title{
CA125 高值と腹水と不正出血を契機に診断された自己免疫性肝炎の一例
}

\author{
定免 渉 ${ }^{1 *}$ 奥津 恵里 ${ }^{2)}$ 増田 友之 ${ }^{3)}$
}

\begin{abstract}
要旨：症例は 60 歳女性, $201 X$ 年 8 月に全身倦总感, 腹部膨満感, 体重増加, 不正出血を主訴に 前医を受診, 多量の腹水と CA125 高值を指摘され当院に紹介となった。 CT および経臸エコー で婦人科悪性腫瘍の存在は否定的で, 腹水細胞診も陰性であった. 初診時より肝機能障害も認め ていたが，入院後の採血で抗核抗体と IgG が上昇していた．腹水コントロール後に肝生検を行 い, 自己免疫性肝炎, 肝硬変に矛盾しない組織像であった。加療により $201 \mathrm{X}+1$ 年 1 月の CT では腹水は消失しており，同年 5 月には CA125 も正常範囲まで低下していた.
\end{abstract}

索引用語： CA125 腹水 肝硬変 自己免疫性肝炎 卵巣癌

\section{はじめに}

Cancer antigen 125 (以下 CA125) は婦人科領域で多 用されている腫瘍マーカーで, 主に卵巣癌の診断や治 療効果判定に用いられている ${ }^{122)}$ 。また肝硬変でも腹水 を伴った例で CA125 の上昇が観察されることが知られ ている(3) .

今回我々は, CA 125 高值, 腹水, 不正出血を契機に 診断された自己免疫性肝炎(Autoimmune hepatitis; 以 下 $\mathrm{AIH}$ )の一例を経験した。当初, 婦人科悪性腫瘍や 原発不明癌が疑われた興味深い症例と考え報告する.

\section{症例}

患者：60 歳, 女性 (閉経後).

主訴：全身倦怠感, 腹部膨満感, 体重増加, 不正出 血.

既往歴：特記事項なし。

家族歴：特記事項なし。

現病歴：201X 年 8 月に全身倊急感, 腹部膨満感, 半 年間で $10 \mathrm{~kg}$ 以上の体重増加, 不正出血を主訴に前医を 受診した。腹部超音波検査で多量の腹水が認められ, 採血で肝機能障害の他に CA125 が上昇していたため, 同年 9 月に精査目的で当科に紹介入院となった。なお 35 歳頃まで職場にて定期検診を受けていたが異常を指

1）奥州市総合水沢病院内科

2) 奥州市総合水沢病院婦人科

3) 岩手医科大学病院病理学講座

*Corresponding author: watarujomen@hotmail.com <受付日2017年9月20日 $><$ 採択日2017年11月16日 >
摘されておらず，退職後は検診を受けておらず受診歴 もなかった。

入院時現症 : 身長 $146.0 \mathrm{~cm}$, 体重 $69.5 \mathrm{~kg}$, 体温 $36.4^{\circ} \mathrm{C}$, 血圧 132/66 mmHg, 脈拍 78/分, $\mathrm{SpO}_{2} 94 \%$ (room). 眼球結膜に軽度の黄染を認め, 腹部は膨満しており波 動を触知した。

入院時血液検査所見（Table 1)：肝胆道系酵素の上 昇, PT 活性の低下を認めた. また腫瘍マーカーでは AFP が軽度上昇しており, CA125が $544 \mathrm{U} / \mathrm{mL}$ と著明に上 昇していた。

腹部造影 CT (Fig. 1a)：多量の腹水貯留を認め, 肝 は萎縮して表面凹凸不整で辺縁が針化していた。

臨床経過（Fig. 2）：婦人科悪性腫瘍を疑い婦人科に 紹介したが, 経腟超音波検查で腫瘍性病変は認められ ず，子宮内膜細胞診も陰性であった。 上・下部消化管 内視鏡検査も行ったが, 腫瘍性病変や静脈瘤は認めら れなかった。

腹水のため腹部膨満感が強く, 呼吸苦や食欲不振, 便秘や不眠の訴えもあったため, フロセミド $40 \mathrm{mg}$ とスピロノラクトン $50 \mathrm{mg}$ を開始した. また腹水穿刺 も行い, 腹水性状は淡黄色漿液性でリバル夕反応陰性, CEA と LDH は正常範囲, 腹水細胞診も提出したが陰 性であった.

肝機能障害も認めていたため, 入院後肝疾患関連の 項目も測定したところ (Table 2), 抗核抗体 (Anti-nuclear antibody ; 以下 ANA) と IgG が上昇していた. AIH, 肝硬変由来の肝機能障害と考え, ウルソデオキシコー ル酸 (以下 UDCA) $300 \mathrm{mg}$ とプレドニゾロン(以下 PSL) $40 \mathrm{mg}$ を開始した. 開始後, トランスアミナーゼ值は速 
Table 1 Laboratory data on admission.

\begin{tabular}{|c|c|c|c|c|c|}
\hline \multicolumn{2}{|c|}{$<\mathrm{CBC}>$} & & & \multicolumn{2}{|c|}{$<$ Coagulation $>$} \\
\hline WBC & $5,300 / \mu \mathrm{L}$ & AST & $150 \mathrm{IU} / \mathrm{L}$ & APTT & $44.0 \mathrm{sec}$ \\
\hline Neutro & $66.8 \%$ & ALT & $97 \mathrm{IU} / \mathrm{L}$ & $\mathrm{PT}$ & $51.1 \%$ \\
\hline Lympho & $24.9 \%$ & ChE & $121 \mathrm{IU} / \mathrm{L}$ & PT-INR & 1.47 \\
\hline Mono & $5.8 \%$ & $\mathrm{LDH}$ & $371 \mathrm{IU} / \mathrm{L}$ & Fibrinogen & $159 \mathrm{mg} / \mathrm{dL}$ \\
\hline Eosino & $2.3 \%$ & ALP & $521 \mathrm{IU} / \mathrm{L}$ & FDP & $25.5 \mu \mathrm{g} / \mathrm{dL}$ \\
\hline Baso & $0.2 \%$ & $\gamma$-GTP & $91 \mathrm{IU} / \mathrm{L}$ & D-dimer & $2.4 \mathrm{mg} / \mathrm{dL}$ \\
\hline $\mathrm{RBC}$ & $366 \times 10^{4} / \mu \mathrm{L}$ & BUN & $12.6 \mathrm{mg} / \mathrm{dL}$ & \multicolumn{2}{|c|}{$<$ Viral marker $>$} \\
\hline $\mathrm{Hb}$ & $11.7 \mathrm{~g} / \mathrm{dL}$ & Cre & $1.64 \mathrm{mg} / \mathrm{dL}$ & HBs-Ag & $(-)$ \\
\hline Hct & $35.0 \%$ & $\mathrm{Na}$ & $140.7 \mathrm{mEq} / \mathrm{L}$ & HBs-Ab & $(-)$ \\
\hline $\mathrm{MCV}$ & $95.6 \mathrm{fL}$ & $\mathrm{K}$ & $3.39 \mathrm{mEq} / \mathrm{L}$ & $\mathrm{HBc}-\mathrm{Ab}$ & $(-)$ \\
\hline $\mathrm{MCH}$ & $32.0 \mathrm{Pg}$ & $\mathrm{Ca}$ & $8.6 \mathrm{mg} / \mathrm{dL}$ & $\mathrm{HCV}-\mathrm{Ab}$ & $(-)$ \\
\hline $\mathrm{MCHC}$ & $33.4 \mathrm{~g} / \mathrm{dL}$ & Glu & $125 \mathrm{mg} / \mathrm{dL}$ & \multicolumn{2}{|c|}{$<$ Tumor marker $>$} \\
\hline Plt & $10.4 \times 10^{4} / \mu \mathrm{L}$ & HbAlc & $5.4 \%$ & CEA & $4.9 \mathrm{ng} / \mathrm{mL}$ \\
\hline$<\mathrm{B}$ & nemistry $>$ & $\mathrm{CRP}$ & $1.67 \mathrm{mg} / \mathrm{dL}$ & CA19-9 & $24.6 \mathrm{U} / \mathrm{mL}$ \\
\hline $\mathrm{TP}$ & $7.1 \mathrm{~g} / \mathrm{dL}$ & $\mathrm{TSH}$ & $1.689 \mu \mathrm{U} / \mathrm{mL}$ & CA 125 & $544 \mathrm{U} / \mathrm{mL}$ \\
\hline Alb & $2.8 \mathrm{~g} / \mathrm{dL}$ & F-T3 & $3.34 \mathrm{pg} / \mathrm{dL}$ & AFP & $15.5 \mathrm{ng} / \mathrm{mL}$ \\
\hline T-bil & $2.04 \mathrm{mg} / \mathrm{dL}$ & F-T4 & $1.45 \mathrm{ng} / \mathrm{dL}$ & sIL-2R & $617 \mathrm{U} / \mathrm{mL}$ \\
\hline
\end{tabular}
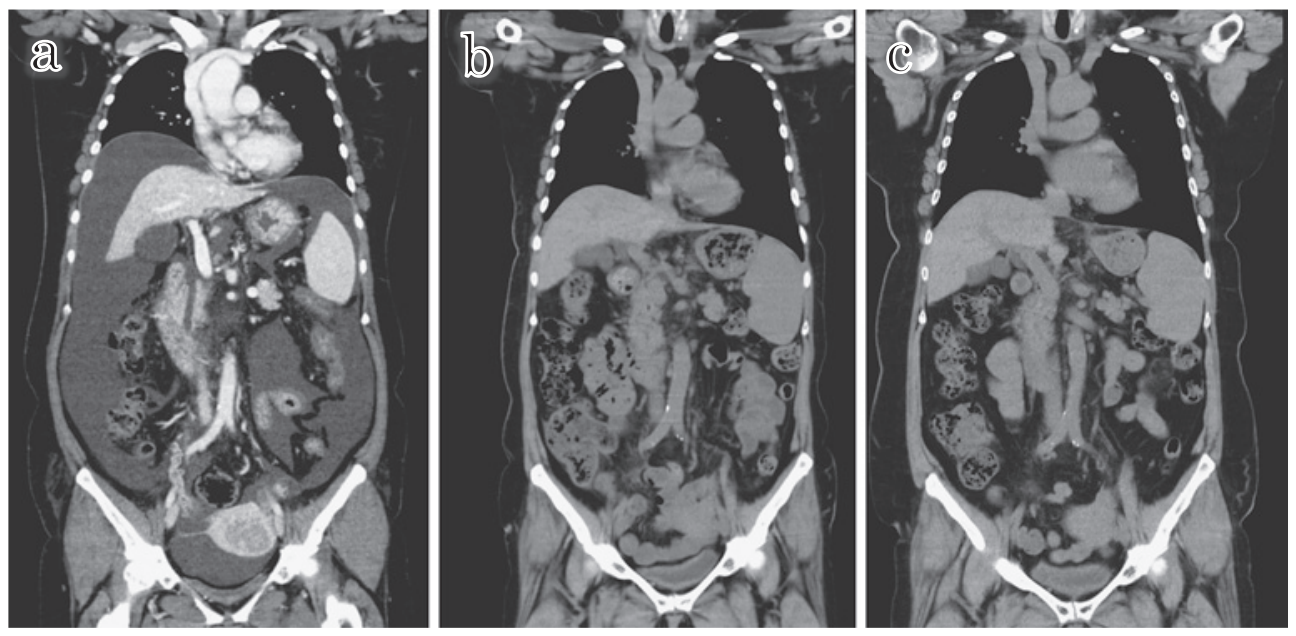

Fig. 1 Findings of CT. (a) A large amount of ascites was accumulated and liver was atrophic, the surface was irregular, the edge was dull. (b) Ascites had disappeared (January 201X+1). (c) Ascites was not observed (August 201X+1).

やかに低下したが，腹水とそれによる諸症状の改善が 得られなかった. フロセミドとスピロノラクトンに加 えトルバプタン $7.5 \mathrm{mg}$ を開始したところ, 腹水は徐々 に減少し体重も以前の状態である $55 \mathrm{~kg}$ 前後まで低下し た. また全身倦怠感や腹水による諸症状も軽減された. 診断目的で肝生検を行ったところ, 病理組織像で線 維性拡大した門脈域にリンパ球および形質細胞の浸潤,
細胆管の増生を認めた(ヘマトキシリンエオジン染色, Fig. 3a, 3b). また再生結節が認められ, 再生結節間に は線維性隔壁が見られた（マッソントリクーム染色, Fig. 3c， 3d). PSL を導入してから 1 カ月以上経過して トランスアミナーゼ值が正常範囲まで低下していたに もかかわらず中等度の interface hepatitis が見られ, 肝 硬変, AIH に矛盾しない所見であった。 なお AIH 国際 


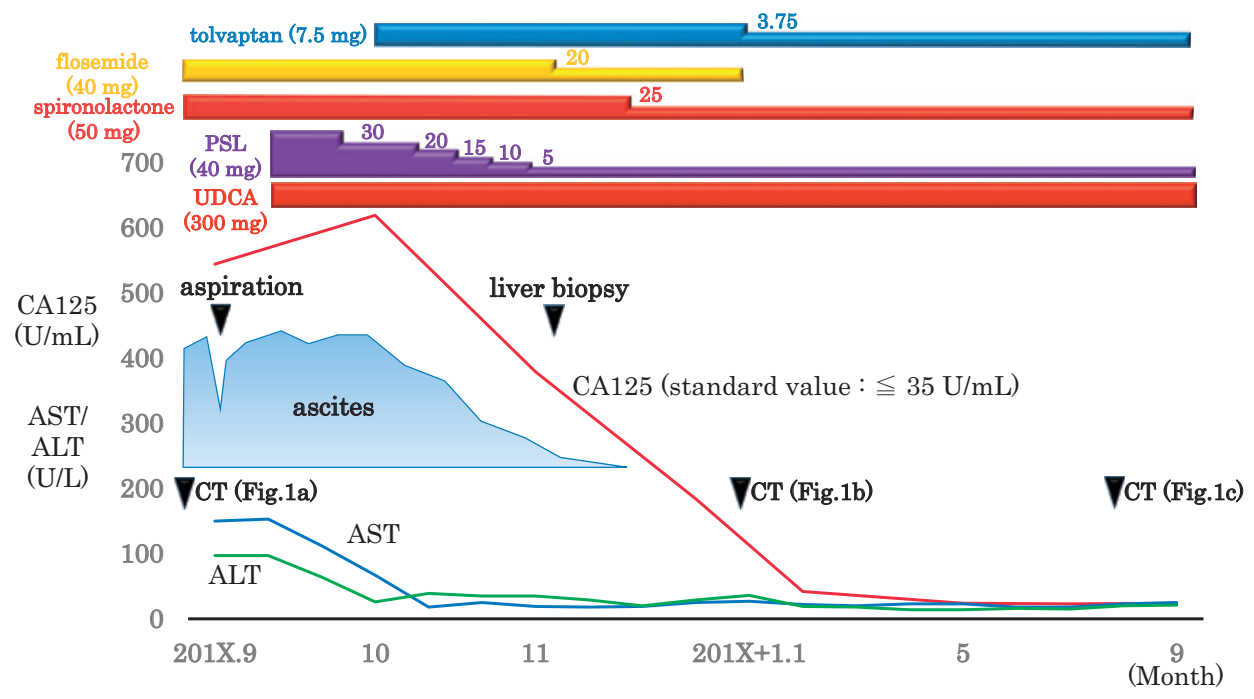

Fig. 2 Clinical course.
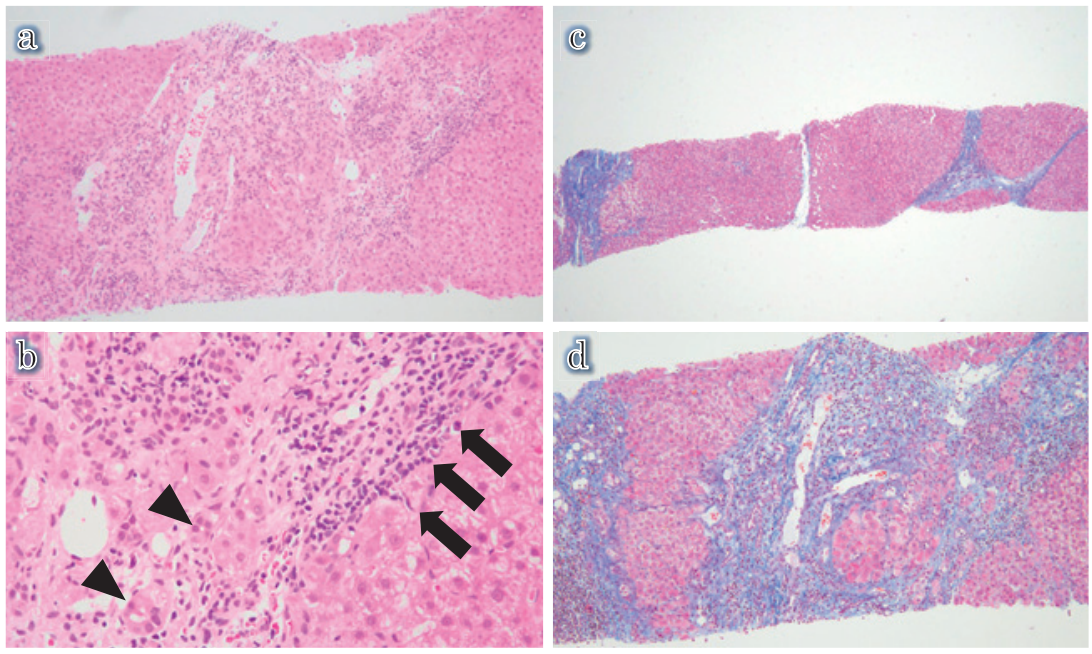

Fig. 3 Histological findings of the liver. (a, b) Lymphocytic and plasmacytic infiltration (arrow), bile ductule hyperplasia (arrowhead) were observed in fibrous enlargement of the portal region (HE stain). (c, d) Regenerative nodules were observed, and fibrous septa were found between them. Moderate interface hepatitis was seen even though more than a month had passed since prednisone induction (Masson trichrome stain).

診断スコアは 19 点, 簡易型スコアは 8 点であり, とも に確定診断の評価であった.

$201 \mathrm{X}$ 年 11 月に退院となり, $201 \mathrm{X}+1$ 年 1 月および 8 月の CT で腹水は認められなかった (Fig. 1b, 1c). また CA125 は最高 $619 \mathrm{U} / \mathrm{mL}$ まで上昇したが, 腹水の
減少とともに徐々に低下して $201 \mathrm{X}+1$ 年 5 月に $24.3 \mathrm{U} /$ $\mathrm{mL}$ と正常範囲となった.

初診時より 1 年以上経過した $201 X+1$ 年 9 月現在も, 腹水は観察されておらず, CA125も $23.3 \mathrm{U} / \mathrm{mL}$ と正常 範囲である。なお不正出血は治療開始後に PT 活性が 
70\%台まで改善してからは見られなくなった.

\section{考察}

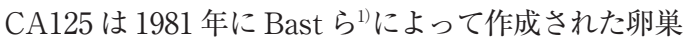
漿液性囊胞腺癌の腹水細胞に対するモノクローナル抗 体 OC125により認識される抗原である. 婦人科悪性腫 瘍の中でも特に卵巣癌で高い陽性率を示す腫瘍マーカー として知られており, Bast ら ${ }^{2)}$ のカットオフ值が $35 \mathrm{U} /$ $\mathrm{mL}$ で，良悪性疾患を鑑別する際に $100 \mathrm{U} / \mathrm{mL}$, 卵巣癌 と他臟器癌を鑑別する際に $500 \mathrm{U} / \mathrm{mL}$ が目安とされて いる.

自験例では初診時に既に CA 125 が $500 \mathrm{U} / \mathrm{m} l$ を超え ており，さらにその 1 カ月後には $600 \mathrm{U} / \mathrm{mL}$ を超えて

Table 2 Laboratory data after admission.

\begin{tabular}{lr}
\hline \multicolumn{2}{c}{$<$ Immunochemistry $>$} \\
ANA & $\geq \times 1,280$ \\
AMA & $(-)$ \\
ASMA & $(-)$ \\
ASMA-M2 & $(-)$ \\
IgG & $2,763 \mathrm{mg} / \mathrm{dL}$ \\
IgA & $443 \mathrm{mg} / \mathrm{dL}$ \\
IgM & $146 \mathrm{mg} / \mathrm{dL}$ \\
& \\
CMV-IgG (EIA) & $(+)$ \\
CMV-IgM (EIA) & $(-)$ \\
EB anti VCA IgG (FA) & 80 \\
EB anti VCA IgM (FA) & $<10$ \\
EB anti EBNA (FA) & 40 \\
\hline
\end{tabular}

いた，主訴が不正出血だったこともあり，当初，卵巣 癌を含む婦人科悪性腫瘍の存在が強く疑われた。また 腹水細胞診が陰性だったものの，腹水が消失して CA 125 が低下するまでは原発不明癌の疑いも捨てきること はできなかった.

腹水を伴った肝硬変でも CA125が高值を示すという

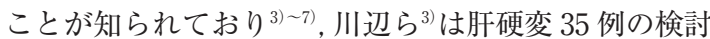
で腹水を有する症例では肝癌合併の有無にかかわらず 有意に CA125 が高值であり, 腹水を認めなかった症例 では大半が正常範囲であったと報告している.また Qureshi ら ${ }^{7)} 130$ 例の肝硬変症例の腹水量を [なし]，［少 量］，[中等量］，[多量］ 4 段階にわけて CA125を測 定したところ，有意に相関して扮り特に [多量］の 41 例のうち 28 例で $500 \mathrm{U} / \mathrm{mL}$ を超えていたと報告してい る.

CA125 が高值を示した非腫瘍性疾患の報告を Table 3 にまとめた。肝硬変以外はクローン病 ${ }^{8)}$, 肝不全 ${ }^{9}$, 甲 状腺機能低下症 ${ }^{10) \sim 12)}$, 心不全 ${ }^{13)}$, ネフローゼ症候群 ${ }^{14)}$, 結核性腹膜火炎 ${ }^{15)}$ 17) であり，これらの報告の中では CA 125 が 1,000 U/mL 以上を示す症例もあり, 自験例と同 様に多量の腹水を伴い当初卵巣癌などの婦人科悪性腫 瘍や原発不明癌が疑われている。また治療により腹水 が減少あるいは消失した症例では CA125 も低下してい る.

その他，月経中，妊娠初期，子宮内膜症，胸膜炎な どでも上昇することがあり,CA125が癌特異的マーカー ではないことがわかる。 なお心不全では胸水や腹水眝 留例で CA125 が上昇し, CA125 高值例で有意に予後が

Table 3 Previous reports of non-neoplastic disease with elevated value of serum CA125 excepting Lc.

\begin{tabular}{|c|c|c|c|c|c|c|c|}
\hline No & Patient & Diagnosis & Ascites & $\begin{array}{l}\text { CA125 } \\
\text { (U/mL) }\end{array}$ & $\begin{array}{l}\text { Outcome } \\
\text { (Ascites) }\end{array}$ & $\begin{array}{l}\text { Outcome } \\
\text { (CA125) }\end{array}$ & References \\
\hline 1 & $26 / \mathrm{F}$ & Crohn's disease & $(+)$ & 190 & disappeared & 35.2 & 8) \\
\hline 2 & $57 / \mathrm{F}$ & Hepatic failure (death) & $(+)$ & 2,203 & - & - & 9) \\
\hline 3 & $74 / \mathrm{F}$ & Hypothyroidism & $(+)$ & 1,059 & disappeared & 43.0 & 10) \\
\hline 4 & $55 / \mathrm{F}$ & Hypothyroidism & $(+)$ & 134 & decreaced & NA & 11) \\
\hline 5 & $78 / \mathrm{F}$ & Hypothyroidism & $(+)$ & 1,255 & disappeared & normal level & 12) \\
\hline 6 & $71 / \mathrm{F}$ & Heart failure & $(+)$ & 198 & NA & NA & 13) \\
\hline 7 & $52 / \mathrm{F}$ & Nephrotic syndrome & $(+)$ & 2,600 & disappeared & 35.0 & 14) \\
\hline 8 & $26 / \mathrm{F}$ & Tuberculous peritonitis & $(+)$ & 925 & decreaced & 196 & 15) \\
\hline 9 & $82 / \mathrm{F}$ & Tuberculous peritonitis & $(+)$ & 385 & disappeared & 32.1 & 16) \\
\hline 10 & $44 / \mathrm{F}$ & Tuberculous peritonitis & $(+)$ & 909 & disappeared & normal level & 17) \\
\hline 11 & $60 / \mathrm{F}$ & Lc (AIH) & $(+)$ & 544 & disappeared & 23.3 & Our case \\
\hline
\end{tabular}

Lc: liver cirrhosis, AIH: autoimmune hepatitis CA125 (standard value: $\leqq 35 \mathrm{U} / \mathrm{mL}$ ) 
不良で入院期間も長期になることが報告されており， 近年予後因子として着目されている13181919).

CA125 は卵巣と子宮内膜の他に胸膜や腹膜でも産生 されている. 肝硬変や心不全, 胸膜炎や腹膜炎などさ まざまな疾患で胸水や腹水が貯留すると刺激されて産 生されると考えられており, 男性でも上昇するのはそ のためである ${ }^{3) ~ 7718119)}$. 自験例では当初 $10 \mathrm{~L}$ 以上腹水が 貯留していて腹水が減少, 消失することで CA125 も低 下していったことから主に腹膜で産生されていたと推 測される.

ところで, CA125を発現している卵巣癌は Mesothelin という蛋白質を発現している腹腔中皮細胞へ高率に転 移することが知られており,CA125-Mesothelineによる 細胞間接着は重要な意義があると考えられている ${ }^{20)}$. Mesotheline は主に胸膜や腹膜などの中皮細胞 (mesothelial cell)に含まれていることから名付けられたが, 卵巣癌自体やその他の癌でも発現している. Sasaki $ら^{21)}$ は卵巣癌患者群と子宮内膜症患者群で Mesotheline と結合した CA125 (以下 $\mathrm{CA} 125^{\mathrm{meso}}$ ) の血清濃度および CA125 ${ }^{\text {meso }}$ と Mesotheline と結合していないCA125 の比 (CA125 $\left.5^{\text {meso }} / \mathrm{CA} 125\right)$ を比較したところ，ともに有意に 卵巣癌患者で高值を示したと報告している。 Pubmed と医学中央雑誌を検索した限り, その他の非腫瘍性疾 患で $\mathrm{CA} 125^{\text {meso }}$ の血清濃度を測定した報告はなかったが, 自験例を含め Table 3 で提示したような疾患では低值を 示すと推測され, 今後 Mesotheline の実臨床への応用が 期待される.

これまで肝疾患などの基礎疾患を指摘されていない 腹水を伴った女性の症例では卵巣癌などの婦人科悪性 腫瘍や原発不明癌に対するスクリーニング目的で CA 125 が測定されることがあると思われる。その際，高值を 示した場合には非腫瘍性疾患でも CA 125 が上昇しうる ことを考慮しつつ, 慎重に診断を進めていくべきと考 えられた。

\section{結語}

CA125高値と腹水と不正出血を契機に診断された AIH 症例を経験した．腹水の減少に伴いCA125が低下し， 腹水消失後は正常範囲で経過していることから, 本症 例では腹水による腹膜刺激により CA125 が産生されて いたと考えられた.
文献

1) Bast RC Jr, Feeney M, Lazarus H, et al. Reactivity of a monoclonal antibody with human ovarian carcinoma. J Clin Invest 1981; 68: 1331-1337

2) Bast RC Jr, Klug TL, St John E, et al. A radioimmunoassay using a monoclonal antibody to monitor the course of epithelial ovarian cancer. N Engl J Med 1983; 309: 883-887

3）川辺隆夫, 平野正憲, 吉田晴彦, 他. 肝硬変肝癌患 者における腹水と CA125 の検討. 肝蔵 $1985 ; 26$ ： 1692

4) Bergmann JF, Bidart JM, George M, et al. Elevation of CA125 in patients with benign and malignant ascites. Cancer 1987; 59: 213—217

5）菅野剛史. 良性疾患での腫瘍マーカーの偽陽性. Lab Clin Pract $1992 ; 10: 127-132$

6) Devarbhavi H, Kaese D, Williams AW, et al. Cancer antigen 125 in patients with liver disease. Mayo Clin Proc 2002; 77: 538-541

7) Qureshi MO, Dar FS, Kholhar N. Cancer antigen125 as a marker of ascites in patients with liver cirrhosis. J Coll Physicians Surg Pak 2014; 24: 232-235

8) Klopocka M, Liebert A, Bielinska J, et al. Diagnostic difficulties in woman with crohn's disease, ascites, and elevated value of serum CA125 antigen. Case Rep Med 2014; 2014: Article ID 981726

9）川井田望, 中村有香, 茅野秀一, 他. 黄疸, 腹水の 出現後, 数ヶ月の経過で肝不全に至った一例. 埼玉 医科大学雑誌 $2007 ; 34: 17$-19

10) Krishnan STM, Philipose Z, Rayman G, et al. Hypothyroidism mimicking intra-abdminal malignancy. BMJ 2002; 325: 946—947

11）深津俊明. 周囲に無関心となり, 動作緩慢と腹部膨 隆で受診した 55 歳, 女性. Lab Clin Pract 2006 ; $24: 59-68$

12) Bou Khalil R, El Rassi P, Chammas N, et al. Myxedema ascites with high CA-125: Case and areview of literature. World J Hepatol 2013; 5: 86—89

13）新谷大輔, 藤原恵一, 長谷川幸清, 他. 腹水貯留, CA125 上昇にて婦人科癌が疑われた急性心不全の 一例. 関東連合産科婦人科学会誌 $2013 ; 50: 477$

14）山下冬樹, 鈴木隆之, 竹内和彦, 他. 経過中 CA 125 の高值を呈した微小変化群によるネフローゼ症 候群の 1 例. 日本内科学会雑誌 $1995 ； 84$ : 951一 953

15）頼 冠名, 栗本悦子, 草野展周, 他. 腹水中 ADA 
高值が診断に寄与した若年女性結核性腹膜炎の 1 例. 感染症学杂倠誌 $2004 ; 78: 916$-922

16) Kuno Y, Iyoda M, Aoshima Y, et al. A case of tuberculous peritonitis in a hemodialysis patient with high soluble interleukin-2 and CA-125 levels. Intern Med 2010; 49: 1783-1786

17) Gosein MA, Narinesingh D, Narayansingh GV, et al. Peritoneal tuberculosis mimicking advanced ovarian carcinoma: an important differential diagnosis to consider. BMC Res Notes 2013; 6: 8

18) Durak-Nalbantic A, Resic N, Kulic M, et al. Serum level of tumor marker carbohydrate antigen-CA 125 in heart failure. Med Arch 2013; 67: 241—244

19) Kaya H, Kurt R, Beton O, et al. Cancer Antigen 125 is Associated with Length of Stay in Patients with Acute Heart Failure. Tex Heart Inst J 2017; 44: 2228

20) Rump A, Morikawa Y, Tanaka M, et al. Binding of ovarian cancer antigen CA125/MUC16 to mesothelin mediates cell adhesion. J Biol Chem 2004; 279 . 9190-9198

21) Sasaki A, Akita K, Ito F, et al. Difference in mesothelin-binding ability of serum CA 125 between patients with endometriosis and epithelial ovarian cancer. Int J Cancer 2015; 136: 1985-1990

本論文内容に関連する著者の利益相反：なし

\title{
A case of autoimmune hepatitis diagnosed with elevated value of CA125, ascites, metrorrhagia
}

\author{
Wataru Jomen ${ }^{1 *}$, Rie Okutsu²), Tomoyuki Masuda ${ }^{3)}$
}

A 60-year-old woman, who had seen in a previous hospital with chief complaints of general malaise, abdominal bloating, weight gain, and metrorrhagia in August 201X, was referred to our hospital because of large ascites and elevated value of CA125. CT and transvaginal ultrasound imaging of gynecologic malignancy and ascitic fluid cytology were all negative. Her liver function had been impaired since the initial visit, but elevated level of ANA and IgG were observed after hospitalization. Histological changes obtained from liver biopsy, which was done after the management of ascites, were consistent with those of autoimmune hepatitis and cirrhosis. After treatment, CT showed ascites had disappeared in January 201X + 1, and CA125 was reduced to normal level in May $201 \mathrm{X}+1$.

Key words: CA125 ascites liver cirrhosis autoimmune hepatitis ovarian cancer

Kanzo 2018; 59: 41-46

1) Department of Internal Medicine, Oshu City General Mizusawa Hospital

2) Department of Gynecology, Oshu City General Mizusawa Hospital

3) Department of Pathology, Iwate Medical University

*Corresponding author: watarujomen@hotmail.com

(C) 2018 The Japan Society of Hepatology 